\title{
Brown fat in the rat: adaptive changes in cold
}

\author{
Robert E. SMITH \\ Department of Physiology, Univ. of California, Los Angeles, USA
}

\begin{abstract}
KURZFASSUNG: Braunes Fett in der Ratte: Adaptive Veränderungen in der Kälte. Bei männlichen Ratten, die einer Umgebungstemperatur von $6^{\circ} \mathrm{C}$ ausgesetzt werden, steigt die Masse des braunen Fetts auf das 2- bis 3 fache, sein $Q_{02}$ (gemessen bei $37^{\circ} \mathrm{C}$ in vitro) etwa auf das Doppelte an. Das Wärmeäquivalent dieser Veränderungen steigt demnach etwa auf das 6 fache des Kontrollwertes. Die entstehende Wärme wird auf dem Blutweg direkt zu den Cervikal- und Thorakalsegmenten des Rückenmarks, zum Herzen und anderen Thorakalorganen gebracht. Die adaptiven Veränderungen im braunen Fett gehen auf hyperplastisches Wachstum durch Zellneubildung aus RES-Vorstufen zurück. Dic $\mathrm{H}^{3}$-markierte DNS-Synthese ist nach 100 Stunden Kälteexposition maximal und wird von einem entsprechenden Maximum des Gewebewachstums gefolgt, das nach 192 Stunden abgeschlossen ist. Sein Abklingen in weiteren 8 bis 16 Tagen entspricht der Beendigung der „shivering"-Periode und dem Auftreten konstanter Organmassen. Das Kälte-Erwachen des winterschlafenden Murmeltieres liefert ein Beispiel für eine "on-off“-Kontrolle der Thermogenese durch braunes Fett. Hier tritt das "shivering" viel später auf.
\end{abstract}

\section{INTRODUCTION}

In previous work (SMrth 1961, 1962a, b, SMITH \& RoBERTs 1964) we have established the role of multilocular brown adipose tissue (cf RASMUSSEN 1924) as a prime thermogenic effector in the defenses of the laboratory rat against exposure to a cold environment. In this it has been shown that, in response to cold, the brown adipose tissue in all sites of occurrence increases in mass and also in $\mathrm{QO}_{2}$ as measured in vitro. By anatomical studies and direct thermometry of the circulatory supplies of these tissues it has also been shown that during cold exposure the heat generated in the loci of brown fat is conveyed by vascular convection directly into cervical and thoracic spinal segments and additionally into the thoracic cage to warm the heart and related structures (SMith, R. E. \& Malveaux, E., unpublished). Thus in vivo the sites of brown fat during cold exposure become centers of thermogenesis wherein the local temperatures rise well above those of the internal viscera and muscle beds. Likewise during the cold-induced arousal of the hibernator (Fig. 1) the temperature of brown adipose tissue rises well in advance of that observed in the body core, as indicated by deep rectal temperature (SMITH \& Hock 1963 of also SMALley \& DreYer 1963).

Concerning the time dependent nature of this response, during cold acclimation we have conducted furcher studies in which mass of tissue, $\mathrm{QO}_{2}$ and cytological changes have been observed in adult male rats exposed to cold $\left(6^{\circ} \mathrm{C}\right)$ for lengths of time 
varying from 3 hours to 70 or more days (SMITH 1962b, CAMERon \& SMITH 1964). These fall into three categories obtained with two series of rats. In the first we employed $\mathrm{H}^{3}$ (tritium) labelled thymidine, injected i.p. one hour prior to time of sacrifice, in order to follow the cellular differentiation of brown fat and other tissues

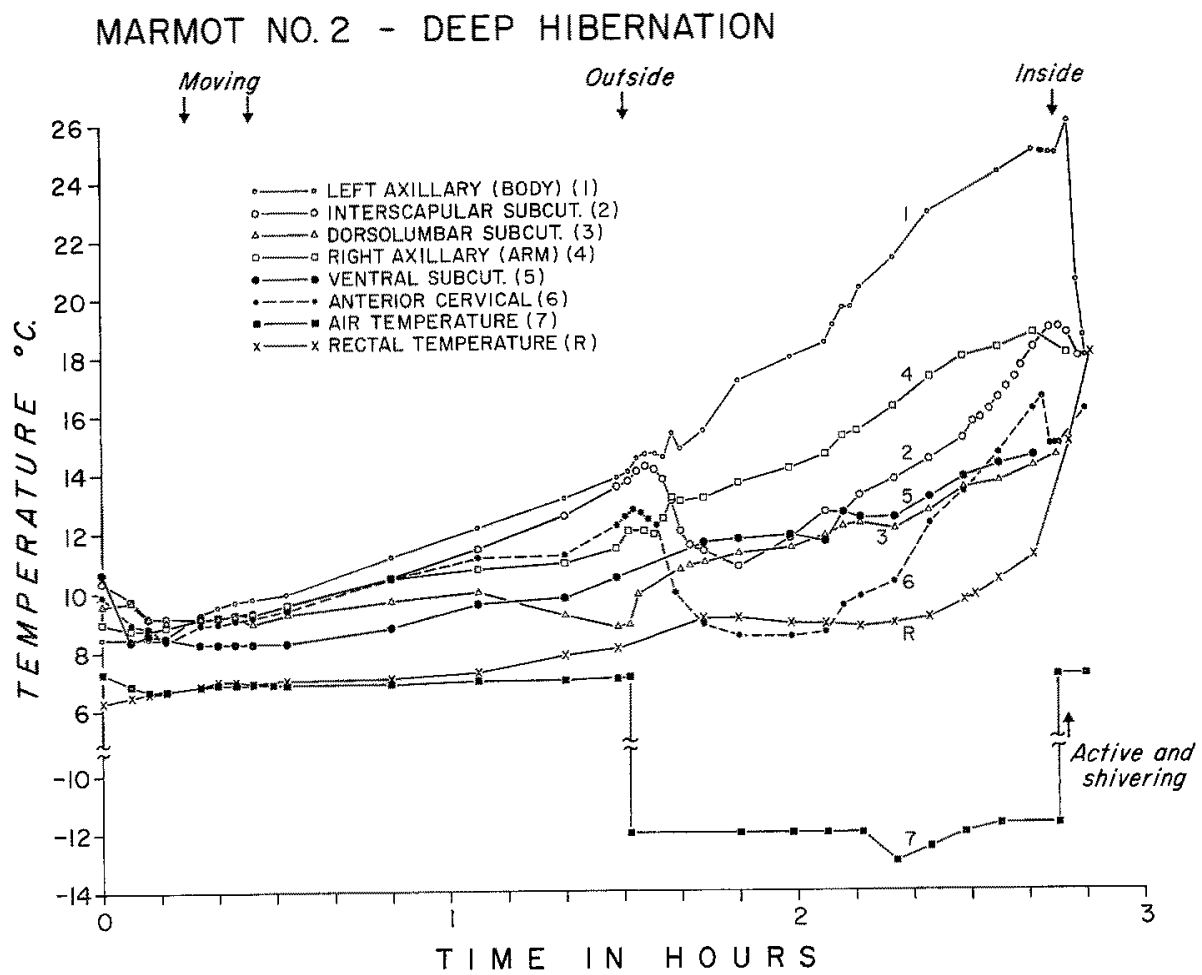

Fig. 1: Temperatures of various sites of brown adipose tissue and other body regions of the marmot (Marmota flaviventris) during cold-induced arousal from deep hibernation.

(After Saith \& Hock 1963, by permission of Science)

during cold exposure of the host. Secondly, rats from a comparable series of coldexposures were killed at various times and their respective organ masses determined. Thirdly, on the same series $\mathrm{QO}_{2}$ of the homogenized brown fat was measured by standard Warburg techniques.

\section{RESULTS}

The results on the tritiated thymidine series demonstrated several features of the histologic and cytologic response of brown adipose tissue to cold exposure (cf SMITH 1962b, Cameron \& SmItH 1964). First it was shown that within the initial 6 to 12 hours in the cold the multilocular fat vacuoles in the brown fat cells were almost completely depleted, accompanied by a general disorganization and evident lipolysis of the neighboring white adipose cells (Fig. 2, a and b). Following this, however, 

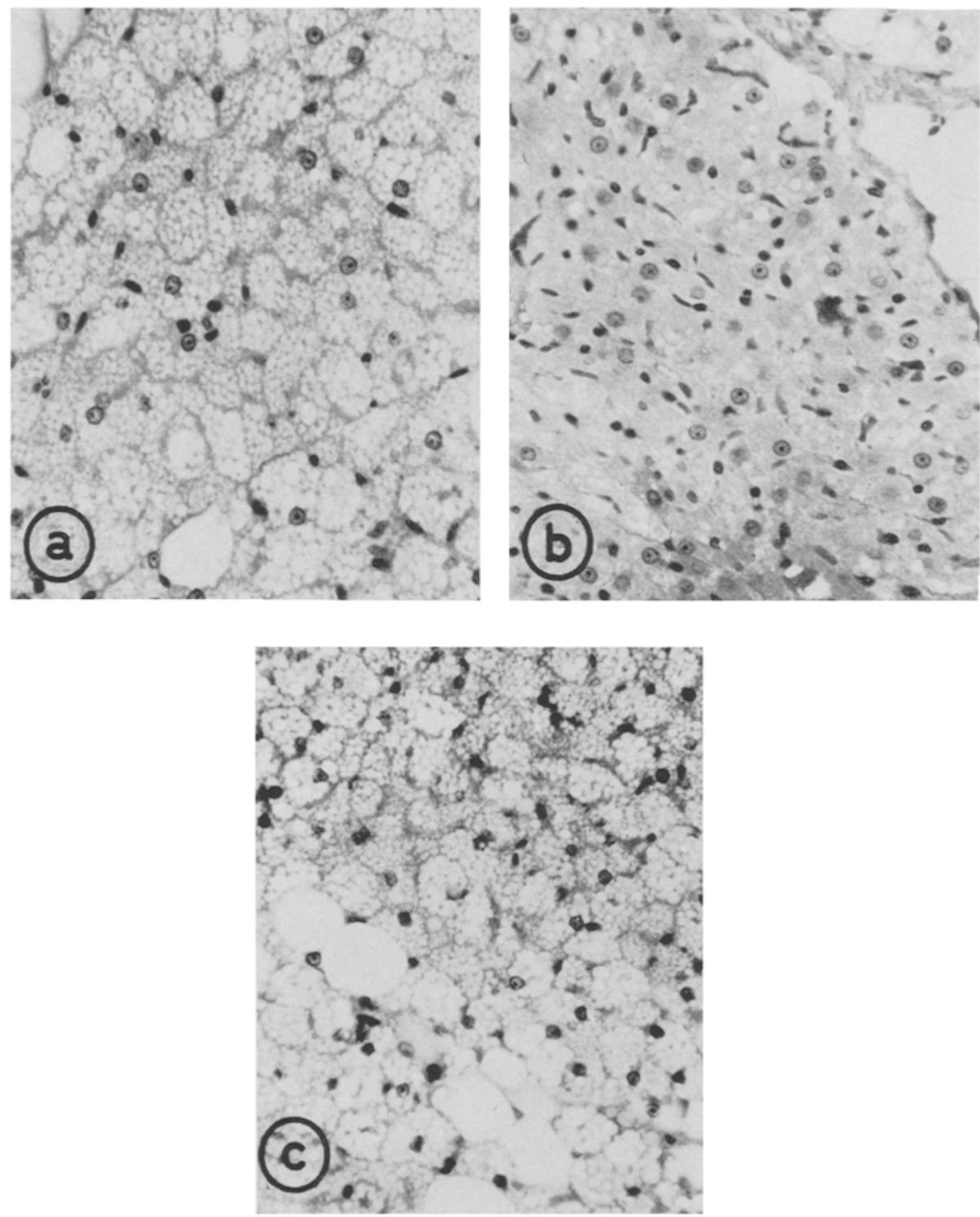

Fig. 2: Photographs of sections of interscapular brown fat taken (a) from an adult rat kept at $26^{\circ} \mathrm{C}$ and $(b)$ a littermate after exposure to cold $\left(6^{\circ} \mathrm{C}\right)$ for 12 hours and $(c)$ a comparable rat after 24 hours exposure to cold $\left(6^{\circ} \mathrm{C}\right)$; Masson's trichrome $\times 750$.

within 24 hours of cold-exposure, the multilocular appearance of the brown fat cells was completely restored to a normally appearing state. The latter then remained throughout an indefinite length of further exposure to cold without appreciable change (Fig. 2. a and c). Concurrent with this, however, was a progressive disappearance of 
the locally occurring white adipose cells and a coincident rise both in vascularity of the tissue and relative numbers of the brown adipose cells.

By observation and counts of the radioautographic $\mathrm{H}^{3}$ thymidine-labelled DNA clusters within the sections of brown adipose tissue, it became evident that (1) no mitotic figures were present in brown adipose cells and (2) that DNA synthesis was occurring only within the reticulo-endothelial elements of the tissue; the latter activity

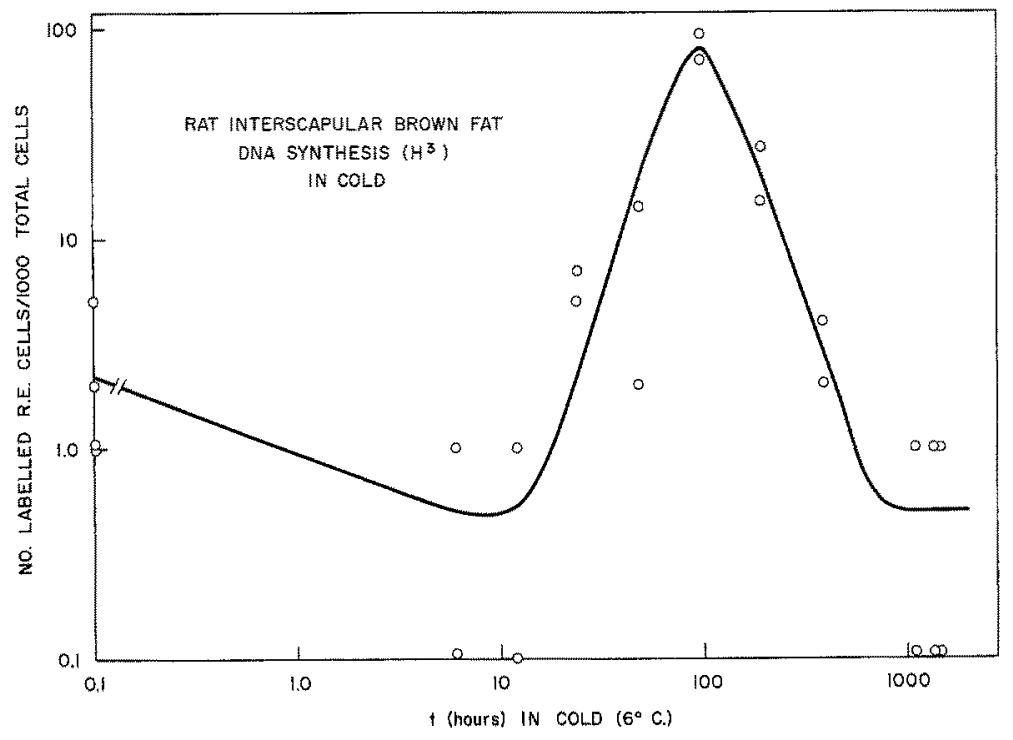

Fig. 3: Plot of frequency of reticulo-endothelial cells exhibiting synthesis of DNA following various times of exposure of the host to cold

reached a peak at the 96 hours cold-exposure period and thereafter declined (Fig. 3) to near normal by the end of the 192 hour period.

To obtain further insight on the cytogenesis of the brown fat cells some rats were exposed to cold for 72 hours and then injected with $\mathrm{H}^{3}$ thymidine, but were not killed at the usual 1 hour post injection but instead held in the cold until 24 and 48 hours thereafter. Since in these animals the labelled DNA clusters were found within brown adipose cells it was concluded that these cells were arising through cytogenesis de novo from reticulo-endothelial precursors, rather than by mitoses of the existing multilocular cells.

Concurrent with the foregoing, histological studies were conducted also upon other tissues of these rats, including white adipose tissue from the epididymal fat pads. Counts of the number of cells per unit area in sections of this tissue showed a progressive rise with exposure time; hence the conclusion was reached that depot fat stores generally were supporting the metabolic requirements and with prolonged exposure to cold continuing slowly toward a state of relative depletion (cf Fig. 4).

For purposes of relating these events to the overall response pattern during chronic cold-exposure, a second series of rats was subjected to a similar program of cold treat- 
ment, though not injected with radiothymidine. These were singly maintained on our standard ration and 12 hours light cycle and routinely killed at 0900 each morning exactly as were those of the previous series (cf SMITH \& RoberT's 1964). All tissues were similarly removed and in this series, instead of being placed in fixative, were

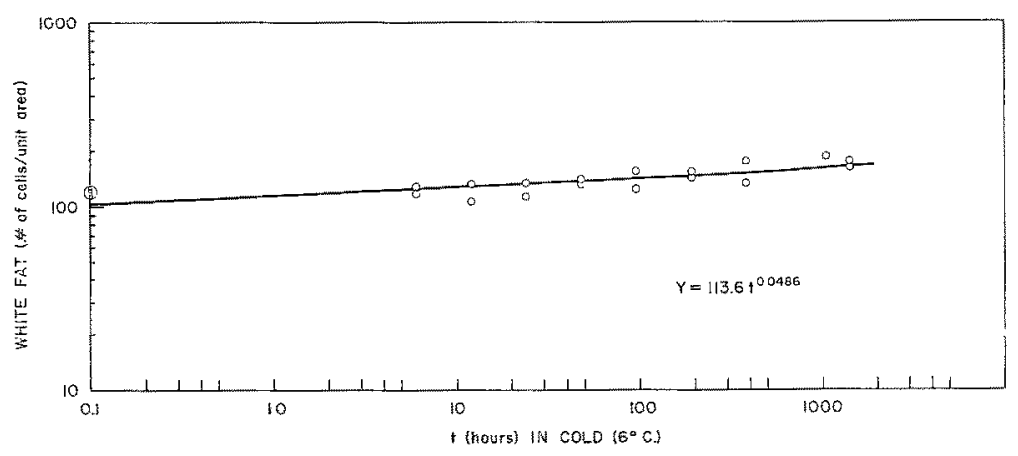

F1g. 4: Numbers of white adipose cells per unit area in sections of epididymal fat from adult male rats exposed to cold for various periods of time

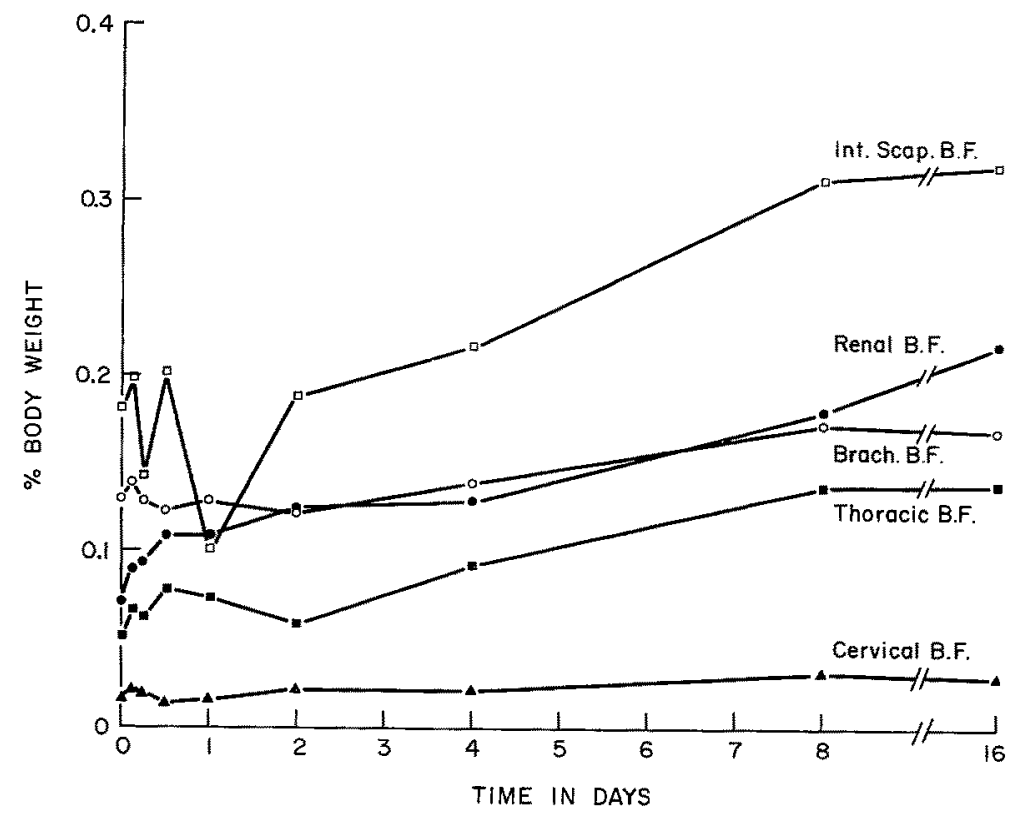

Fig. 5: Wet mass of epididymal fat and of brown adipose tissue from the major sites of deposition in rats, plotted as a function of time in cold

weighed with minimal water loss, and homogenates of brown fat tissues were made in $0.25 \mathrm{M}$ sucrose for use in respiratory assays. Exposure sequences were likewise randomized as in the preceding series.

Results of this experiment indicated some interesting trends in hyperplastic growth of the brown fat in response to the cold-exposure. Thus it was found that the 
peak of DNA synthesis observed earlier in the first series at 96 hours was indeed prognostic of a peak in hyperplastic development of brown adipose tissue, which in theory (cf CAmEron \& Greulich) should have occurred some 72 hours later. Examination of the curves of tissue mass versus time in cold (Fig. 5) obtained in the second series shows clearly that in all sites of brown fat the maximum growth rate occurred in the interval between the 96 and 192 hour points. Following this period the growth rate declines appreciably; notably, the tissue mass appears to reach an essentially steady state by the end of the first 16 days exposure, although it increases slowly thereatter, but mainly in relation only to total body weight.

$\mathrm{QO}_{2}$ values (Fig. 6) concurrently obtained with the homogenates of brown fat, also show a rising trend with longer exposure times. Aside from the transient fall at the

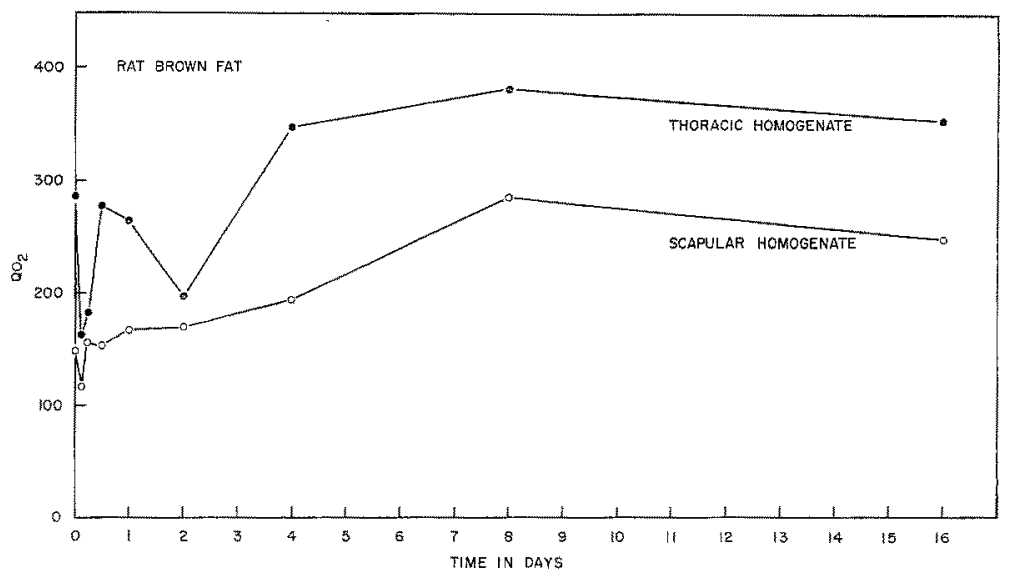

Fig. 6: $\mathrm{QO}_{2}$ in $\mu \mathrm{O} \mathrm{O} / \mathrm{mg} \mathrm{N} / \mathrm{hr}$ of homogenates of brown adipose tissues taken respectively from thoracic and interscapular sites in rats exposed to cold for various times up to 60 days. Points are mean values from 4 to 6 animals at each time. System and procedure as follows: Into $5 \mathrm{ml}$ Warburg flasks, with $0.05 \mathrm{ml} \mathrm{10 \%} \mathrm{KOH}$ in center wells, were placed $0.5 \mathrm{ml} 1: 10$ brown fat homogenate in $0.25 \mathrm{M}$ sucrose, and $0.5 \mathrm{ml}$ of reaction mixture containing in $\mu$ moles, ATP, 2 ; $a$-ketoglutarate, $10 ; \mathrm{KF}, 10 ; \mathrm{MgCl}_{2}, 5 ; \mathrm{PO}_{4}$ as $\mathrm{KH}_{2} \mathrm{PO}_{4}(\mathrm{pH} 7.4$ ), 15; tris buffer ( $\mathrm{pH} 7.4$ ), 25; glucose, 25 and hexokinase, $25 \mathrm{kM}$ units. The latter two were tipped into the system from the side arm at the time of the first readings. Final reaction volume was $1 \mathrm{ml}$ equilibrated with $\mathrm{O}_{2}$ and incubated at $37^{\circ} \mathrm{C}$. Mean Kjeldahl nitrogen content of homogenate per flask was $0.41 \mathrm{mg}$ for thoracic brown fat and $0.50 \mathrm{mg}$ for the interscapular

3 and 6 hour points, $\mathrm{QO}_{2}$ generally rises over the initial 16 days of the exposure to cold and thereafter remains more or less steady or may rise somewhat further, as occurred in the interscapular tissue.

Two aspects of this development appear relevant to the question of acclimation to cold. One that has already received notice (SMith 1961, 1962b, SMith \& Rober'ts 1964, SMTTH \& Holjer 1962) is the obvious fact that heat production as given by the product of tissue mass multiplied by $\mathrm{QO}_{2}$ is raised by the respective rises in both of these factors. The second derives from the approximate coincidence in the time of achievement of this steady state with that of the disappearance of shivering in chronically cold-exposed rats (cf SMrTH \& HOIJER 1962). On the argument that brown adipose tissue acts during cold exposure principally as a thermogenic tissue, one may 
infer that for the rat cold acclimation is achieved when the thermal contribution from this tissue becomes sufficient to raise the cephalic blood temperature above that of the shivering threshold. In general, by the end of two weeks in the cold there has also been an appreciable rise both in $\mathrm{QO}_{2}$ and relative mass of some of the major viscera including heart.

One may also speculate on the mechanism by which the brown adipose tissue may reach its apparently new steady state of mass in response to a given level of environmental cold. Three features of the development are (1) the initial depression of $\mathrm{QO}_{2}$ as measured in vitro and (2) the initial lag phase in cytogenesis, both corresponding with (3) the period of depletion in the intracellular multilocular fat vacuoles. From an examination of figure 2 one is also struck with the rapidity of disappearance of local white adipose cells, which becomes virtually complete by the 192 hour period, and the rise in apparent vascularity of the tissue by 48 hours. Clearly seen also is the concurrent depletion of white fat depots elsewhere in the body. Evidently the initial phase entails an immediate attad upon the intracellular storage, which becomes replaced at the expense of local white fat and is subsequently maintained by vascular transport of fat from other storage sites.

As these adaptive responses become morphologically apparent under stress, they reflect target effects of neural and neurohumoral outputs arising as an integrated response of the intact organism. Thus, in respect to thermogenesis, the hypertrophy of brown adipose tissue is a resultant of synergistic action on part of both thyroid and adrenocortical activity together with somatotrophic principles. Deriving from hypothalamico-hypophyseal channels, these join with autonomic-sympathetic outflows to enhance the overall exchange of materials and essential energy-yielding reactions to meet the hypothermic threat of a cold environment.

\section{SUMMARY}

1. Brown adipose tissue has been earlier shown in this laboratory to represent a highly vascularized thermogenic effector system which in response to cold supplies heat to cervical and thoracic neural and visceral elements.

2. In respect to rats, evidence is adduced to show that during cold exposure the hyperplastic development and rising $\mathrm{QO}_{2}$ of the brown adipose tissue coincides in point of time with the gradual disappearance of the shivering thermogenesis normally occurring during the first two or three weeks of exposure.

3. Factors which may limit the amount and hyperplastic rate of growth of the tissue are suggested.

\section{LITERATURE CITED}

Cameron, I. L. \& Greulich, R. C., 1963. Evidence for an essentially constant duration of DNA synthesis in renewing epithelia of the adult mouse. J. Cell. Biol. 18, 31-40.

- \& SMith, R. E., 1964. Cytological responses of brown fat tissue in cold exposed rats. J. Cell. Biol. (in press). 
Rasmussen, A. T., 1924. The so-called hibernating gland. J. Morph. 38, 147-205.

Smalley, R. \& Dreyer, R., 1963. Brown Fat: Thermogenic effect during arousal from hibernation in the bat. Science 140,1333-1334.

SмiтH, R. E., 1961. Thermogenic activity of hibernating gland in the cold-acclimated rat. Physiologist 4, 113.

- 1962a. Thermoregulation by brown adipose tissue in cold. Federation Proc. 21, 221.

- 1962b. The physiological role of brown adipose tissue. Proceedings of the 2 nd Symposium on Natural Mammalian Hibernation, 1962, Helsinki. Ed. Pafyo Suomalainen. Ann. Acad. Sci. Fenn. A:IV:71, 1964.

- \& Hock, R. J., 1963. Brown Fat: Thermogenic effector of arousal in hibernators. Science 140, 199-200.

- \& Holjer, D. J., 1962. Metabolism and cellular function in cold acclimation. Pbysiol. Rev. $42,60-142$.

- \& Roberts, J. C., 1964. Thermogenesis of brown adipose tissue in cold-acclimated rats. Am. J. Physiol. 206, 143-148.

\section{Discussion following the paper by SMrTH}

KINNE: Congratulations on this fine piece of work. I have several questions. To begin with, what is the minimum period of time required to initiate measurable changes in the mass of brown fat tissue?

SMrTH: From preliminary data on intact rats obtained with thermisters and thermocouples suitably arranged in tissues and various intravascular locations, we find that the thermogenic response of brown fat to a cold challenge may occur within a period of less than one minute. This response appears to be subject to very rapid "on-oft" control, mediated probably by the sympathetic-autonomic nervous system.

KINNE: Is the amount of response different in young and adult individuals?

SMrth: We have no direct evidence; however Werss $(1957$, Am. J. Physiol, 188, 430) has shown that capacity of rats for satisfactory cold acclimation goes through a maximum at about the 3 months age level. Although the original study emphasized thyrotrophic aspects of this response, it can be noted here that hyperplastic activity of brown fat is remarkably sensitive to thyroid hormone and to a synergistic effect of cortico-steroid action, as LACHANCE \& PAGÉ have shown $(1953$, Endocrinology 52,57$)$. Very probably also the cold resistance of neonatal rodents may be dependent upon the relatively high proportion of brown fat present in the body at that stage.

KINNE: Is there a correlation between the amount of response and total metabolic rate?

Sмxтн: May I take this question to mean the correlation between thermogenic activity of brown fat and total body metabolism?

KINNE: Yes, that is correct.

Sмrтн: On the basis of purely aerobic metabolism, one might not find a very clear relationship due to a varying degree of anaerobic heat production which may occur in this tissue. Among the latter are probably those which Mokrasch (1960, Am. J. Physiol. 199, 950) has ascribed to the acyl phosphates in order to account for the early anaerobic phase of the heat production of the hibernator during arousal, and the ATP depletion observed in the hearts of such animals by ZIMMX $(1960$, Bull. Mus. comp. Zool. Harv. 124, 455). Additionally available are probably the very considerable heats of hydrolysis from the degradation of esterified triglycerides, abundantly present in brown fat and rapidly used during acute cold exposure, as partially suggested by our present findings. Among the aerobic reactions one would include all of the major metabolic pathways leading to terminal electron transfer by either the direct or indirect oxidative routes. In general these would be expected to undergo activation in proportion to 
the sympathetic adrenergic supply and to other neurohumoral factors. Oxidative activity is accentuated also by the high frequency of mitochondria in close association with the multilocular fat vacuoles within the cytoplasm. Finally, the abundant vascularity of the tissue and its high sensitivity to norepinephrine (HANNON \& LARSON 1962, Am. J. Physiol. 203, 1055) suggests an unusual capacity of the tissue to exchange materials in proportion to the increasing cardiac output accompanying the acute response to cold. Likewise our own findings on the increasing oxidase activity of this tissue during development of acclimation to cold suggests a fairly close correlation between aerobic metabolism and cellularity of the tissue with the metabolism of the whole animal.

KINNE: Did you obtain indications as to differences in the response patterns due to the season?

SMrTH: This question relates well to the previous ones in that all of the changes noted above do show considerable sensitivity to neurohumoral factors which are themselves seasonally influenced; many such effects have been recorded in amount, composition and cellular properties of brown fat (see Johansson 1959, Metabolism 8, 221; Remiliard 1958, Ann. N. Y. Acad. Sci. 72 Art. 1, 1-68).

KINNE: If rapid changes in outside temperature have almost immediate functional as well as structural consequences, the resulting fast "on-off" responses would "gear" the organism in a rapid sequence into different directions, probably at the cost of extra energy. On the grounds of efficiency considerations, one might have expected a somewhat less sensitive compensatory mechanism. Maybe the individual is not only capable of acclimating to high or low environmental temperature but also to rather constant versus changing temperature patterns.

SMITH: Our experience with both rats and hibernators has impressed us with the extreme lability of the temperature changes of the interscapular and superior cervical sites of brown fat. We find also that these areas may coincidentally change temperatures in opposite directions at times, from which it appears that their respective controls are possibly under relatively independent effector mechanisms.

LANGER: Ich möchte darauf hinweisen, daß das braune Fettgewebe bei Embryonen eine große Menge Glykogen im Cytoplasma der plurivakuolären Fettzellen enthält. Nach Untersuchungen von Schierer (1956, Zool. Beitr. N. F. 2, 63-125) an Wanderratten verschwindet dieses Glykogen während der Geburt innerhalb ganz kurzer Zeit, so daß schon bei einem nur wenige Stunden alten Neugeborenen nichts mehr davon nachweisbar ist. Es scheint mir naheliegend, diesen Glykogenverlust mit dem Aufbau der - bei der Ratte zunächst freilich nur beschränkten - Temperaturregulation des Neugeborenen in Zusammenhang zu bringen.

SмIтн: This appears entirely possible. As we have indicated elsewhere, the relative abundance of brown adipose tissue in neonates, both human and rodent, would also suggest an early thermoregulatory role for this tissue (cf. Mount 1963 [SMTTH, R. E. in discussion]; Responses to thermal environment in newborn pigs, Fed. Proc. 22 (3), and cf. 1964, Ann. Acad. Sci. Fenn. A: IV, 71).

LANGer: Wurde die Relation der Meßgröße für den $\mathrm{O}_{2}$-Verbrauch (Energieproduktion) zur Menge der lipoidfreien Trockensubstanz berechnet? Verschiedene physiologische Größen bleiben, auch unter Schwankungen von Neutralfett und Wassergehalt, bei Bezug auf das Trockengewicht des lipoidfreien Materials konstant. Auch ist der Ruhe- $\mathrm{O}_{2}-$ Verbrauch von braunem und weißem Fettgewebe gleich, wenn man ihn auf dieses Bezugssystem berechnet. Es wäre interessant zu wissen, ob nach dem ersten plötzlichen Anstieg der Aktivität, der wohl sicher in der vorhandenen Masse an Cytoplasma erfolgen muß, die ständig erhöhte Aktivität während Dauer-Unterkühlung von der gleichen Cytoplasma-Menge geleistet wird oder ob eine Vermehrung der Cytoplasma-Masse erfolgt. Es ist also die Frage, ob der geleistete Energieumsatz im Gewebe, bezogen auf die lipoidfreie Trockensubstanz, auch bei langdauernder Wärmeproduktion größer ist als in Ruhe.

SMrTH: $\mathrm{O}_{2}$-consumption of brown fat slices and homogenates is higher in cold-acclimated than in normal rats, whether estimated on basis of wet weight of tissue or upon nitrogen content. We have not referred any of the data to dry weight; however, the far greater number of white 
fat cells in the brown adipose tissue of normal compared to cold-acclimated rats would tend to depress $\mathrm{qO}_{2}$ of the former on either a wet or dry weight basis. The residual difference obtained on basis of $\mathrm{N}$ content evidently reflects a qualitative difference in cellular composition of the active protoplasmic mass in the respective samples. Certainly there is evidence that in response to cold, the brown fat tissues undergo byperplasia, with resulting increase in cellular number and total mass. As the vascular cellularity increases as well, both of these developments proceed concurrently with the depletion of unilocular (white) adipose cells within the tissue. Additionally, there is the early transient cycle of diminution in the multilocular fat vacuoles of the brown adipose cells. Thus the latter response may support the early thermogenesis of the tissue, i. e. during the initial hours of cold-exposure, while the chronic phases are supported by the hyperplasias leading to greater tissue mass. The latter, however, should also present a pattern of enhanced enzyme activities in order to support the raised $\mathrm{qO}_{2}(\mathrm{~N})$.

LOCKER: Is it not a contradiction that in the cold-acclimated rat, brown fat contributes so much to non-shivering thermogenesis, whereas in the hibernator it brings about arousal, a process connected with dramatic shivering?

Smith: As described in a recent paper (Sмrтh \& Hock 1963, Science 140, 199) the brown fat appears to act in the hibernating animal as a thermogenic effector during initiation of coldinduced arousal; in this the thermogenic action in the anterior regions clearly precedes the shivering phase. Thus shivering comes into greatest prominence, in the marmot at least, only after the forward regions are relatively awake and after the deep rectal temperature has risen toward $20^{\circ} \mathrm{C}$. This delayed but rapid rise in rectal temperature appears to involve a general opening up of the posterior vascular supply to effect a thermal equilibration of the general blood temperature at an intermediate value. In the cold-acclimated rat it appears that brown fat acts mainly as a thermal jacket which overlies and warms the incoming vascular returns from the periphery while also supplying heat by convective transfer to the upper spinal segments and the organs of the thoracic cage. 